\title{
DE
}

DE GRUYTER

OPEN

Arch. Min. Sci. 62 (2017), 4, 911-928

Electronic version (in color) of this paper is available: http://mining.archives.pl

DOI 10.1515/amsc-2017-0062

LEI ZHANG*, ZHIWEI YE*\#, JUN TANG**, DINGYI HAO**, CUN ZHANG*

\section{COMPARATIVE EXPERIMENT STUDY ON NITROGEN INJECTION AND FREE DESORPTION OF METHANE-RICH BITUMINOUS COAL UNDER TRIAXIAL LOADING}

\author{
EKSPERYMENTY I BADANIA PORÓWNAWCZE EFEKTÓW WSTRZYKIWANIA AZOTU \\ I SWOBODNEJ DESORPCJI NA WĘGLU BITUMICZNYM O WYSOKIEJ ZAWARTOŚCI METANU \\ W WARUNKACH OBCIĄŻEŃ TRÓJOSIOWYCH
}

\begin{abstract}
As a kind of associated geological gas, coalbed methane (CBM) is mainly adsorbed in the coal seam. The coal-methane adsorption phenomenon can be described by Langmuir monolayer adsorption model, BET multilayer adsorption model and the Theory of Volume Filling of Micropore (TVFM), whereas the binary gas adsorption phenomenon can be described by the extended Langmuir Model. For the CBM in the low permeability coal seam, the amount of gas released by direct drainage is relatively limited, which cannot eliminate the gas explosion and outburst hazards. Gas injection is an effective method to promote methane drainage. In this paper, the free desorption and nitrogen injection displacement experiments are comparatively analyzed, which allows verifying the effectiveness of nitrogen injection's enhancement to gas drainage. The experiment of injecting nitrogen gas into the coal body shows that the coal fracture can be maintained or expanded by the injected gas pressure so that more methane can be released. The nitrogen injection has a higher time efficiency than that of free desorption as well. The displacement ratio of $\mathrm{N}_{2} / \mathrm{CH}_{4}$ is in the range of 1-3. Both the injection pressure and confining pressure affect the displacement ratio. The analysis of the desorbed gas components shows that the relationship between the methane component and gas flooding time is an "inverted S" shape curve, and the appropriate time for the methane collection can be inferred by the time interval of the rapid decline of the curve.
\end{abstract}

Keywords: Gas Injection; Methane; Displacement Ratio; Free Desorption

Metan zawarty w złożu węgla występuje w głównej mierze w postaci zaadsorbowanej, jako gaz związany. Zjawisko adsorpcji metanu na węglu opisuje model adsorpcji jednowarstwowej Langmuira, model adsorpcji wielowarstwowej BET oraz teoria objętościowego wypełniania mikroporów. Z kolei

* KEY LABORATORY OF DEEP COAL RESOURCE MINING (MINISTRY OF EDUCATION OF CHINA), SCHOOL OF MINES, STATE KEY LABORATORY OF COAL RESOURCES AND SAFE MINING, CHINAUNIVERSITY OF MINING \& TECHNOLOGY, XUZHOU, JIANGSU 221116, CHINA

** SCHOOL OF SAFETY ENGINEERING, CHINAUNIVERSITY OF MINING \& TECHNOLOGY, XUZHOU, JIANGSU 221116, CHINA

\# Corresponding author: cereal_god@126.com; DINGYI HAO, E-mail: hdy@cumt.edu.cn 


\begin{abstract}
procesy desorpcji mieszanin dwóch gazów opisuje rozszerzony model Langmuira. W przypadku metanu zawartego w złożu węgla o niskiej przepuszczalności, ilość gazu uwalnianego poprzez proste odgazowanie jest ograniczona i wciąż nie eliminuje ryzyka wybuchu gazu oraz wyrzutu skał i gazu. Wstrzykiwanie gazów jest jedną ze skutecznych metod odgazowania. W pracy tej przeprowadzono badanie porównawcze rezultatów swobodnej desorpcji gazu oraz wstrzyknięcia do złoża azotu, w celu zademonstrowania skuteczności odgazowania poprzez wprowadzenie azotu. Eksperyment polegający na wstrzykiwaniu azotu do calizny węglowej pokazuje możliwość zachowania lub powiększenia pęknięć w strukturze węgla pod działaniem ciśnienia wstrzykiwanego gazu, co umożliwi uwolnienie większych ilości metanu. Ponadto, wprowadzenie azotu okazuje się rozwiązaniem skuteczniejszym w dłuższym okresie czasu niż swobodna desorpcja. Stosunek wypierającego metan $\mathrm{N}_{2}$ do $\mathrm{CH}_{4}$ wynosi w przybliżeniu 1:3. Zarówno ciśnienie wstrzykiwanego gazu jak i wielkość ciśnienia złożowego mają wpływ na tempo wypierania metanu przez azot. Analiza składników desorbowanego gazu wskazuje, że zależność ilości metanu od czasu wypływu gazu opisywana jest na wykresie krzywą w postaci odwróconej litery S, zaś odpowiedni czas na odzysk metanu odczytujemy jako przedział odpowiadający nagłemu obniżeniu widocznemu na wykresie.
\end{abstract}

Slowa kluczowe: wstrzykiwanie gazu, metan, tempo wypierania, swobodna desorpcja

\title{
1. Introduction
}

Coalbed methane (CBM) is a kind of associated geological gas, with methane being its main component. On the one hand, CBM is a major hazard to mining safety production; on the other, $\mathrm{CBM}$ itself can be perceived as a natural and clean energy. It would bring enormous economic benefits if we could drain and utilize CBM in a proper way. Therefore, gas extraction is very meaningful to the safety of production and the economic efficiency.

The direct gas drainage is often difficult to achieve in the low permeability coal seam if no other auxiliary measures are carried out. At present, there are two technical ways to improve gas drainage effect. One approach adopts the artificial methods to improve the permeability of the coal seam, including high-pressure water injection, hydraulic fracturing, hydraulic slotting, loose blasting, large diameter borehole et al. These techniques can often increase the amount of gas release periodically, but the duration of the effect is short.

The other approach is reasonable borehole layout and drilling parameters optimization. In theory, the denser the borehole layout, the more evident the effect of gas extraction, but the dense borehole layout often equals to complex construction, poor applicability, and high cost. Therefore, a more efficient, more applicable method of CBM drainage is required.

In the late twentieth century, the San Juan basin in the United States succeeded in injecting $\mathrm{CO}_{2}$ into the coal seam to improve the recovery of coalbed methane $\left(\mathrm{CO}_{2}\right.$-ECBM) (Reeves et al., 2004). The test results show that, by injecting a certain amount of $\mathrm{CO}_{2}$ or $\mathrm{N}_{2}$ into the coal seam, the life of the gas well can be prolonged. Compared with the method of reservoir pressure depletion, the recovery rate of coalbed methane can be increased by $15-20 \%$. The success of the ECBM test provides us a new idea about the coal seam gas injection to promote methane drainage.

The theoretical basis of coal seam gas injection is built on Darcy flow theory, Fick's diffusion theory and the theory of gas adsorption. The migration of coalbed methane in ECBM process is a very complex process, including the competitive adsorption-desorption, diffusion and Darcy flow of coalbed methane. The adsorption and desorption of gas will cause the expansion and contraction deformation of coal and rock, which will lead to the change of pore structure and then to the change of permeability of coal and rock. The change of pore structure and permeability of coal and rock affects the flow of gas in coal and rock. Based on an energy balance approach, Pan and Connell (2007) derived a theoretical model to describe adsorption-induced coal swell- 
ing at adsorption and strain equilibrium, which can be applied to $\mathrm{N}_{2}$-enhanced coalbed methane recovery. The analysis of a field trial of gas mixture enhanced CBM by Fang et al. (2013) revealed that the G-ECBM technology integrated with underground methane drainage systems can provide an effective method to enhance the CBM recovery and hence improve the mining safety. Reeves and Oudinot (2004a; 2004b) carried out a reservoir modeling study based on the Tiffany Unit $\mathrm{N}_{2}$-ECBM pilot; the economic result and future field performance were forecast. After the parallel ECBM displacement simulation experiments, Wang et al. (2015) found that Coal seam permeability significantly affects the effect of $\mathrm{CO}_{2}$ or $\mathrm{N}_{2}$ flooding $\mathrm{CH}_{4}$ and $\mathrm{CO}_{2}$ as an injected gas is superior to $\mathrm{N}_{2}$. After reviewing the ECBM pilots projects in America and Europe, Oudinot et al. (2007) found that coal permeability is reduced with $\mathrm{CO}_{2}$ injection due to swelling, and is enhanced by $\mathrm{N}_{2}$ injection. Based on the geomechanical and sorption characteristics of the coal, Sayyafzadeh and Keshavarz (2016) optimized the composition of the mixture of $\mathrm{CO}_{2}$ and $\mathrm{N}_{2}$ to acquire a better economic result. Zhang et al. $(2015 ; 2016)$ studied the enhanced gas drainage process by the self-developed Multi-Function Outburst Research Rig and found that $\mathrm{N}_{2}$ flushing has a significant impact on the $\mathrm{CH}_{4}$ desorption and removal from coal.

Based on the research on the displacement behavior of $\mathrm{CH}_{4}$ adsorbed on coals, Shimada et al. (2005) revised the EL model (extended Langmuir equation) to obtain a more accurate prediction about the sorbed ratio of multicomponent gases on coals. The pure and mixture gas adsorption experiment by Busch et al. $(2003 ; 2006)$ showed that only a few measurements showed preferential adsorption of $\mathrm{CO}_{2}$ and preferential desorption of $\mathrm{N}_{2}$, as commonly expected, and the degree of hysteresis, i.e. deviation of sorption and desorption isotherms shows no dependence on coal rank. Zhang et al. (2014) found that the sorption capacity and hysteresis of coal can be influenced with coal particle sizes. The numerical simulation of Yang et al. (2010) shows that the gas drainage of carbon dioxide injection is better than that of nitrogen injection, but the research of Fang et al. (2009) showed that the injected carbon dioxide may reduce the coal permeability, which is the disadvantage of methane emission.

Generally speaking, there are three aspects of the reasons for CBM injection's enhancement effect on gas drainage. One is increasing coal seam permeability, thus enabling more methane seepage with coerced released; another is reducing the CBM partial pressure, promoting methane desorption in coal seam; the third is injecting gas for the competitive adsorption and gas replacement adsorption effect so that more methane can desorb. However, due to the differences in the formation conditions, occurrence conditions and coal quality characteristics of CBM in different mining areas, the results of gas drainage vary. However, method of gas injection's enhancement has shown good consistency.

This paper briefly introduces CBM generation and storage mechanism, and then focuses on the theory of gas adsorption in porous media. The following main part of this paper includes gas flooding experiment design, experimental implementation system, data processing and analysis, theory and the resulting discussion.

\section{Adsorption theory and gas injection mechanism}

The CBM is formed in different stages of coalification (Tao et al., 2005; Zhang et al., 2007). The thermal and biological origins are the main CBM formation sources (Smith et al., 1997; Kotarba, 2001). Although coal is a reservoir rock for gas, it differs significantly from conventional petroleum reservoirs in that the volume of gas, which it can store, exceeds its open pore volume 
by an order of magnitude. The volume of pores in coal is small and the majority of gas in coal consists of adsorbed gas which covers the surfaces of micropores (Murry, 1991; Scott, 2002; Saghafi, et al., 2007; Yi et al., 2009).

The methane is mainly adsorbed in the coal pore fissures. The injection of other gases into the coal seam has broken the original adsorption equilibrium of the coal gas, changed the gas composition of the original CBM, and reduced the adsorption partial pressure of methane. In this part of the paper, three classic adsorption models are interpreted.

\subsection{Classic adsorption models}

Based on the hypothesis of surface adsorption site, Langmuir derived a most popular solid-gas two-phase adsorption model (Langmuir, 1918). The isothermal adsorption equation of Langmuir is usually expressed by the following formula:

$$
\frac{V}{V_{L}}=\frac{P}{P+P_{L}}
$$

Where $V$ is the adsorbed volume at equilibrium pressure $P, V_{L}$ is the maximum monolayer capacity, also known as the Langmuir volume, $P_{L}$ is the Langmuir pressure; it refers to the pressure when the sorbed volume is half of the Langmuir volume $V_{L} / 2$.

According to the BET theory, the physical adsorption of solid to gas is the result of van der Waals force. The van der Waals force not only exists between the gas molecules but also between solid to gas molecules. Hence, the solid-gas adsorption can form a multimolecular layer. The adsorption energy of solid to gas forms the first molecular layer and the adsorption energy of gas to gas forms the second and the rest adsorbed molecular layers. Actually, the BET model can describe the different types of isothermal adsorption curves (Lowell \& Shields, 1984; Harpalani, 2006).

The BET theory is also a surface adsorption model, but it is a multi-molecular layer adsorption model. The following formula is generally used to describe the isothermal adsorption of solid to gas.

$$
\frac{1}{V\left(P_{0} / P-1\right)}=\frac{1}{V_{m} C}+\frac{C-1}{V_{m} C} \frac{P}{P_{0}}
$$

Where $V_{m}$ is the monolayer volume, $C$ is a constant, $P_{0}$ is the saturation vapor pressure. The larger the value of $C$, the earlier that the multilayer formation occur.

Based on the Polanyi adsorption theory, Dubinin proposed the Theory of Volume Filling of Micropore (TVFM) to explain the adsorption phenomena in porous media. Dubinin and Astakhov proposed an equation representing the isotherms that obeyed the TVFM. Known as the DubininAstakhov (D-A) equation, it is expressed as

$$
V=V_{0} \exp \left[-D\left\{\ln \left(\frac{P_{0}}{P}\right)\right\}^{n}\right]
$$

Where $V$ is the amount adsorbed; $V_{0}$ is the volume of micropores; $n$ is the structural heterogeneity parameter, a small number varying between 1 and $4 ; D$ is a constant for a particular 
adsorbent-adsorbate system and is equal to $(R T / \beta E)^{n}$, where $E$ is the characteristic energy of the adsorption system and $\beta$ is the adsorbate affinity coefficient. $P_{0}$ is the saturation vapor pressure of the adsorbate at temperature $T$, and $P$ is the equilibrium vapor (or free gas) pressure (Harpalani, 2006).

Dubinin and Radushkevich suggested that the value of $n=2$ may be appropriate for some cases, and the equation (D-R equation) can be modified as

$$
V=V_{0} \exp \left[-D\left\{\ln \left(\frac{P_{0}}{P}\right)\right\}^{2}\right]
$$

The adsorption of porous media to mixture gases is usually described by the extended Langmuir model. The extended Langmuir binary gas adsorption model is expressed by the following equations:

$$
\begin{aligned}
& V_{1}=V_{L 1} \frac{P_{1}}{P_{L 1}\left(1+P_{1} / P_{L 1}+P_{2} / P_{L 2}\right)} \\
& V_{2}=V_{L 2} \frac{P_{2}}{P_{L 2}\left(1+P_{1} / P_{L 1}+P_{2} / P_{L 2}\right)}
\end{aligned}
$$

Where $V_{1}$ and $V_{2}$ are the adsorption amount of coal to each gas in the mixture; $P_{1}$ and $P_{2}$ are the adsorption partial pressure of each gas in the mixture at the state of adsorption equilibrium; $V_{L 1}$ and $V_{L 2}$ are the Langmuir volume of each gas; $P_{L 1}$ and $P_{L 2}$ are the Langmuir pressure of each gas.

TABLE 1

Characteristics of different adsorption models

\begin{tabular}{|c|c|c|c|c|}
\hline \hline & Langmuir Model & BET Model & DR / DA Model & Extended Langmuir \\
\hline $\begin{array}{c}\text { Basic } \\
\text { Assumptions }\end{array}$ & Adsorption Sites & Adsorption Sites & $\begin{array}{c}\text { Volume Filling of } \\
\text { Micropore }\end{array}$ & Adsorption Sites \\
\hline $\begin{array}{c}\text { Adsorbate } \\
\text { Distribution }\end{array}$ & $\begin{array}{c}\text { Monolayer } \\
\text { Molecule }\end{array}$ & $\begin{array}{c}\text { Multilayer } \\
\text { Molecule }\end{array}$ & $\begin{array}{c}\text { Micropore } \\
\text { Coalescence }\end{array}$ & Monolayer Molecule \\
\hline Applicability & Solid to Single Gas & Solid to Single Gas & Solid to Single Gas & Solid to Mixed Gas \\
\hline
\end{tabular}

The Langmuir model is simple and effective, and the parameters in the equation have definite physical meanings. Langmuir volume and Langmuir pressure are important parameters for the economic evaluation of CBM. BET model is seldom used to the economic evaluation of CBM, but, it is widely used for the determination of specific surface area. Both Langmuir model and BET model explain solid gas adsorption from the surface adsorption perspective. However, DR or DA model explain the solid gas from the overlap of adsorption potential on pore surface perspective, which results in the aggregation of gas molecules in some pores. The extended Langmuir model retained all the assumptions of Langmuir theory. And it is considered that each component will carry out adsorption competition at each active site. That is to say, the potential adsorption sites are equal for each adsorbate components. 


\subsection{Analysis of the mechanism of gas injection enhancement in gas drainage}

When the nitrogen is injected into the coal seam, the effective partial pressure of methane is reduced from the perspective of Langmuir monolayer adsorption theory. With the decrease of the effective partial pressure of methane, the methane adsorption capacity of coal will be reduced, so more methane will be desorbed from coal. According to the theory of BET multilayer adsorption and TVFM, the decrease of methane partial pressure will also reduce the adsorption of coal to methane. Therefore, one of the theoretical foundations of improving the gas drainage rate by gas injection is that the effective partial pressure of methane can be reduced after gas injection.

The three gases show different sorption capacity to coal, and the preferential sorption sequence of the three gases is $\mathrm{CO}_{2}>\mathrm{CH}_{4}>\mathrm{N}_{2}$. The parameter $b$ in the Langmuir equation, the parameter $C$ in the BET equation, the parameter $D$ in the D-P equation, are all related to the polarity of the gas molecules, which means the coal has different affinity to different gas molecules. When the carbon dioxide or nitrogen is injected into the coal seam, carbon dioxide or nitrogen can compete with methane to form a competitive adsorption or displacement adsorption phenomenon, so that more methane is desorbed from coal.

The CBM exists in the coal medium in two forms: adsorption and free state. Before gas injection, the CBM is in a relatively stable state. After gas injection, the pressure of the mixed gas in the coal seam is increased, which helps to maintain or increase the coal seam fracture opening. Because of the pressure potential, the mixed gas flows in the fracture, what promotes the release of $\mathrm{CBM}$.

\section{Experimental design of gas injection displacement}

This experiment aims to study the feasibility of gas injection to improve the methane drainage. In order to verify that gas injection can improve the gas drainage, it is necessary to set up the control group. The free gas desorption experiment and gas flooding experiment are carried out under the same conditions, and the amount of released methane and experiment influence factor are comparatively analyzed.

\subsection{Sample collection and preparation}

In this paper, the experimental coal samples were taken from the $8 \#$ coal seam of Xutuan coal mine in Suzhou of Anhui Province, China. The coal quality parameters of $8 \#$ coal seam are shown in Table 2. Derived from underground coal after drilling, the lump coal was cut and ground into cylindrical coal. The coal sample specifications are $\phi 50 \mathrm{~mm} \times 50 \mathrm{~mm}, 125 \mathrm{~g}$.

TABLE 2

The coal quality parameters of $8 \#$ coal seam in Xutuan coal mine

\begin{tabular}{|c|c|c|c|c|c|}
\hline \hline Volatile (Vr) & $\begin{array}{c}\text { Bond index } \\
\text { (GR.I) }\end{array}$ & Ash (Aad) & Sulfur Content & $\begin{array}{c}\text { Phosphorus } \\
\text { Content }\end{array}$ & Calorific Value \\
\hline $30 \sim 37.5 \%$ & $>85 \%$ & $15 \sim 25 \%$ & $<1.0 \%$ & $<0.01 \%$ & $2.7 \times 107 \mathrm{~J} / \mathrm{kg}$ \\
\hline
\end{tabular}


The perceptual description of the experiment coal sample is as follows: overall, the coal sample has great brittleness, $2 \sim 3$ joints cover the two sections, transverse joints and vertical joints developed on the sample profile, the coal beside the joints is shining brightly.

\subsection{Experimental device}

The experiment system is a self-developed Gas Flow and Displacement Testing Apparatus (GFDTA). In this paper, the instrument is used to carry out the comparative experiment of the free desorption and $\mathrm{N}_{2}$ injection displacement $\mathrm{CH}_{4}$. The main parts and gas-pipeline are shown in Fig. 1.

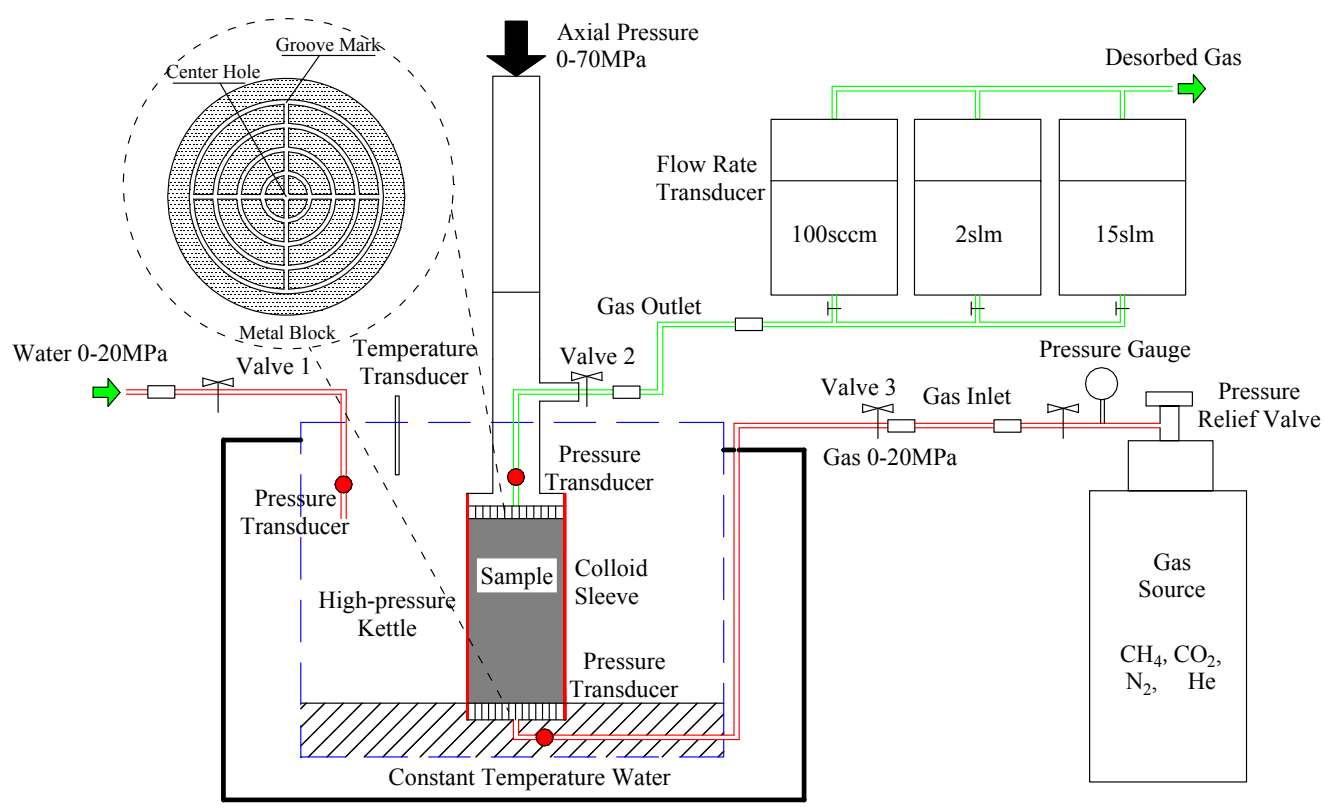

Fig. 1. The principle structure schematic diagram of the GFDTA

\subsection{Experimental scheme}

Before the free desorption and displacement desorption can proceed, the coal-methane adsorption needs to reach adsorption equilibrium. Hence, the long-time coal-methane adsorption must be carried out before the main part of the experiment. The flow meter in the downstream of the high-pressure kettle will measure the flow rate, and we can calculate the amount of released methane. The desorbed gas is collected every 3 minutes with the sampling bag, and the gas composition is analyzed with the gas chromatographic analyzer.

In order to simulate the occurrence of gas in the coal seam, the long-time adsorption experiment is carried out. Due to the limitation of the experimental conditions, the adsorption after 10 hours is assumed to have reached adsorption equilibrium. The experimental design of longtime adsorption is shown in the following Table 3. 
Free desorption experiment could simulate field boreholes gas drainage to some degree, free desorption experiment design under different conditions as shown in the following Table 4.

To be able to compare the experiment of gas injection displacement with the free desorption experiment, it should be carried out under the same conditions. The experimental design of gas injection displacement under different conditions is shown in the following Table 5.

Long-time adsorption experiment design under different condition

\begin{tabular}{|c|c|c|c|c|}
\hline \hline \multirow{2}{*}{ Adsorption Gas } & \multirow{2}{*}{$\begin{array}{c}\text { Adsorption } \\
\text { Time / } \mathbf{h}\end{array}$} & \multicolumn{2}{|c|}{ Confining Pressure / MPa } & $\begin{array}{c}\text { Adsorption Pore } \\
\text { Pressure / MPa }\end{array}$ \\
\cline { 3 - 5 } & \multirow{3}{*}{$\mathrm{CH}_{4}$} & Axial & Radial & 1.5 \\
\cline { 3 - 5 } & \multirow{2}{*}{10} & 2 & 2 & 1.5 \\
\cline { 3 - 5 } & & \multirow{3}{*}{3} & 3 & 2.0 \\
\cline { 3 - 5 } & & & & 2.5 \\
\hline
\end{tabular}

Free desorption experiment design under different conditions

\begin{tabular}{|c|c|c|c|}
\hline \multirow{2}{*}{ Free Desorption Gas } & \multicolumn{2}{|c|}{ Confining Pressure / MPa } & \multirow{2}{*}{$\begin{array}{l}\text { Adsorption Pore } \\
\text { Pressure / MPa }\end{array}$} \\
\hline & Axial & Radial & \\
\hline \multirow{4}{*}{$\mathrm{CH}_{4}$} & 2 & 2 & 1.5 \\
\hline & \multirow{3}{*}{3} & \multirow{3}{*}{3} & 1.5 \\
\hline & & & 2.0 \\
\hline & & & 2.5 \\
\hline
\end{tabular}

TABLE 5

$\mathrm{N}_{2}$ injection displacement experiment under different conditions

\begin{tabular}{|c|c|c|c|c|c|}
\hline \multirow{2}{*}{$\begin{array}{l}\text { Injection } \\
\text { Gas }\end{array}$} & \multirow{2}{*}{$\begin{array}{l}\text { Displaced } \\
\text { gas }\end{array}$} & \multicolumn{2}{|c|}{ Confining Pressure / MPa } & \multirow{2}{*}{$\begin{array}{c}\text { Adsorption Pore } \\
\text { Pressure /MPa }\end{array}$} & \multirow{2}{*}{$\begin{array}{l}\text { Injection Inlet Gas } \\
\text { Pressure/MPa }\end{array}$} \\
\hline & & Axial & Radial & & \\
\hline \multirow{7}{*}{$\mathrm{N}_{2}$} & \multirow{7}{*}{$\mathrm{CH}_{4}$} & 2 & 2 & 1.5 & 1.5 \\
\hline & & \multirow{6}{*}{3} & \multirow{6}{*}{3} & \multirow{3}{*}{1.5} & 1.5 \\
\hline & & & & & 2.0 \\
\hline & & & & & 2.5 \\
\hline & & & & \multirow{2}{*}{2.0} & 2.0 \\
\hline & & & & & 2.5 \\
\hline & & & & 2.5 & 2.5 \\
\hline
\end{tabular}

Confining pressure is used to simulate the in situ stress, the axial pressure and radial pressure is exerted by the GFDTA to realize the confining pressure. Henceforth in this paper, when referring to confining of $2 \mathrm{MPa}$, we mean that both axial pressure and radial pressure are $2 \mathrm{MPa}$. The parallel experiments are carried out under different conditions hence the experimental conditions are simplified. Henceforth in this paper, Desorption 2-1.5 and Displacement 2-1.5-1.5 refer to the experiment condition. The first number refers to the confining pressure; the second number refers to the adsorption pressure; the third number refers to the injection pressure. Hence, Desorption 2-1.5 is the free desorption experiment of confining pressure $2 \mathrm{MPa}$ and adsorption 
pressure 1.5 MPa; Displacement 2-1.5-1.5 is the nitrogen injection displacement experiment of confining pressure $2 \mathrm{MPa}$, adsorption pressure 1.5 MPa and injection pressure 1.5 MPa.

\subsection{Experimental procedure}

\section{Long-time adsorption experiment}

After the coal sample is loaded into the high-pressure kettle, the axial pressure and radial pressure are set up according to the experiment design. The pressure relief valve of the pipeline system is opened; the methane is injected into the high-pressure kettle. The outlet valve of the high-pressure kettle is closed when the original gas is exhausted. The methane is still injected into the high-pressure kettle until the gas pressure is higher 0.2-0.4 MPa than the designed value, then the inlet valve is closed. The coal sample is kept in the confined space for 10 hours.

\section{Free desorption experiment}

After 12 hours of adsorption, the flow meter at the downstream of the pipeline is checked to ensure it is performing as required. The outlet valve is opened (the opening of the valve should be consistent each time) to release methane for 30 minutes, and the gas flow rate is recorded continuously by the flow meter.

\section{Nitrogen injection displacement experiment}

Nitrogen is injected into the high-pressure kettle to displace the methane in the coal sample. After 12 hours of adsorption, the flow meter at the downstream of the pipeline is checked to ensure it is performing as required. At the same time, the vacuumed sample bag is being prepared, and the desorbed gas is collected every 3 minutes. Nitrogen source is connected to the inlet of the pipeline, and the inlet gas pressure is adjusted in accordance with the above experiment design. Then, the inlet and outlet high-pressure kettle is opened (the opening of the valve should be consistent each time), the gas flooding begins.

At the same time, the inlet and outlet of the autoclave body are opened (the opening of the valve should be consistent each time), desorbed gas is collected every 3 minutes for 30 minutes. At last, the gas composition in the sample bags is analyzed with the gas chromatographic analyzer.

\section{Experiment results and analysis}

\subsection{Long-time adsorption under different conditions}

Long-time adsorption simulated the occurrence state of CBM. Under laboratory conditions, the coal sample is loaded into the closed high-pressure kettle, and axial pressure and radial pressure are applied to simulate the in-situ stress. The coal-methane adsorption in the confining space lasts for 12 hours, meanwhile, the gas pressure in the closed high-pressure kettle is monitored. The variation of gas pressure with time under different confining pressures and different initial pressures is shown in the following Fig. 2.

As can be seen from the figure above, in the first 120 minutes of long-term adsorption, gas pressure drops rapidly. After 120 minutes, the gas pressure is relatively stable and flat. The higher initial gas pressure results the larger decreasing amplitude. Free methane is gradually reduced due to adsorption. At the same time, the microscopic damage of methane pressure on 


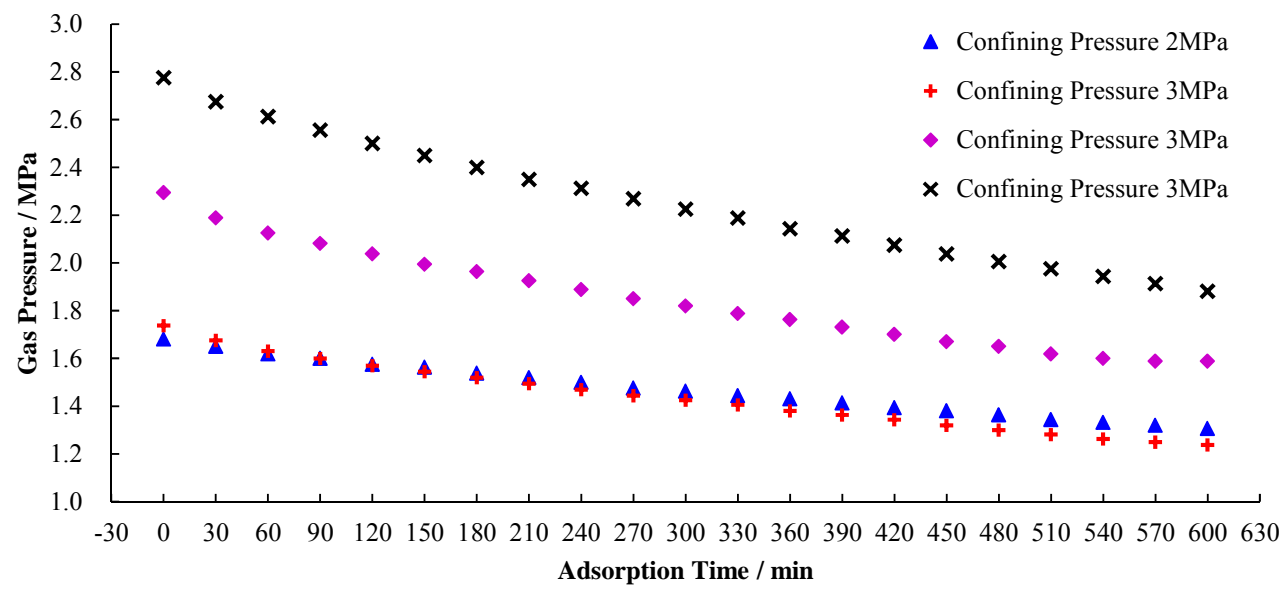

Fig. 2. The variation of gas pressure with time in long-time adsorption

coal porous media is also changing. There are a lot of microporous structures in the coal body, some of which are not connected. The methane gas in coal pore and fracture pressure distribution is not balanced and stable, due to the presence of gas pressure potential in the micropore fracture, micropore structure of coal body will be damaged, which will blind holes and cracks. It is generally believed that the adsorption reaction and desorption reactions are transient, but the effect of methane gas diffusion in the pore system and the coal straddle structure damage over time is slowly advancing, the concentration of methane molecules in the micropore only reached a certain conditions, leaving the question whether the gas molecule would be adsorbed on the surface of the medium. The larger the initial gas pressure is, the more evident the gas diffusion in the micropores and the microscopic damage to the porous media will be.

In addition, in the figure above, when the initial gas pressure is the same, the pressure drop of the confining pressure of $3 \mathrm{MPa}$ is slightly larger than that of the confining pressure of $2 \mathrm{MPa}$. In this paper, it is speculated that when the confining pressure is small, the higher initial gas pressure can facilitate the penetration of methane gas into the coal sample pore system, but the gas pressure damage to the coal structure is weaker. When the confining pressure is higher, the effect of initial gas pressure is not enough to make the methane gas diffuse into the whole coal sample system rapidly, but the micro damaging of gas pressure to coal is ongoing. The final result is the higher of the confining pressure, the larger of gas pressure drop.

\subsection{Comparative analysis of methane emission volume}

In order to compare the methane emission volume generated in 30 minutes under different conditions, the following column chart (Fig. 3) is drawn from the experiment data.

As can be seen from Fig. 3, when the coal samples are subjected to the same conditions, the methane emission volume of injected nitrogen flooding in 30 minutes is much larger than that of the free desorption methane. When the confining pressure is $2 \mathrm{MPa}$ and the adsorption pressure is $1.5 \mathrm{MPa}$, the methane emission volume of free desorption is $620.99 \mathrm{~mL}$, and the methane emission of nitrogen flooding is $978.99 \mathrm{~mL}$. If the methane emission amount of nitrogen 
flooding was taken as the baseline, the methane emission volume of free desorption accounts for $63.4 \%$. When the confining pressure is $3 \mathrm{MPa}$ and the adsorption pressure is $1.5 \mathrm{MPa}$, the methane emission volume of free desorption is $604.70 \mathrm{~mL}$, the methane emission volume is 986.41 $\mathrm{mL}, 1095.43 \mathrm{~mL}, 1166.34 \mathrm{~mL}$ when the injection pressure is $1.5 \mathrm{MPa}, 2.0 \mathrm{MPa}, 2.5 \mathrm{MPa}$, respectively; the methane emission of free desorption accounts for $61.3 \%$, and the methane emission increment was $9.95 \%$ and $6.47 \%$ after the injection pressure was increased by $0.5 \mathrm{MPa}$. When the confining pressure is $3 \mathrm{MPa}$ and the adsorption pressure is $2.0 \mathrm{MPa}$, the methane emission volume of free desorption is $835.14 \mathrm{~mL}$, the methane emission volume is $1145.62 \mathrm{~mL}$ and $1371.86 \mathrm{~mL}$ when the injection pressure is $2.0 \mathrm{MPa}$ and $2.5 \mathrm{MPa}$, respectively; the methane emission of free desorption accounts for $72.9 \%$, and the methane emission increment was $19.7 \%$ after the injection pressure was increased by $0.5 \mathrm{MPa}$. When the confining pressure is $3 \mathrm{MPa}$ and the adsorption pressure is $2 \mathrm{MPa}$, the methane emission volume of free desorption is $839.43 \mathrm{~mL}$, and the methane emission of nitrogen flooding is $1963.47 \mathrm{~mL}$, the methane emission volume of free desorption accounts for $42.8 \%$.

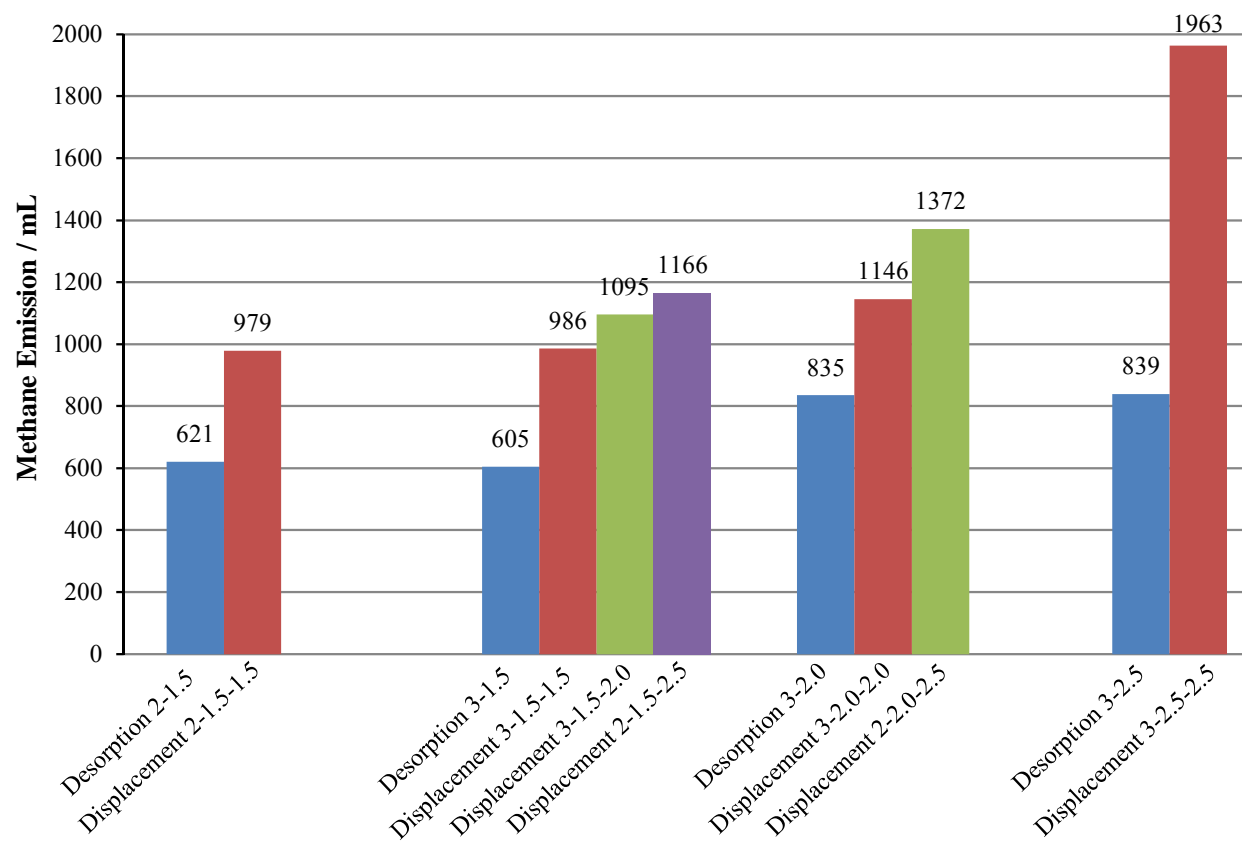

Fig. 3. The methane emission volume under different conditions

In order to analyze the methane emission volume's relationship with experiment time, the following figure (Fig. 4) was generated based on the experimental data. The single exponential function with offset is found to preferably describe the growth trend of methane emission with displacement time. The curves in Fig. 4 are the single exponential function with offset fitting curve.

Compared with methane emission of the free desorption, the enhancement of nitrogen injection to methane emission shows good consistency. However, for different experimental conditions, displacement desorption showed different characteristics. When the confining pressure of 
coal sample is $3 \mathrm{MPa}$ and the adsorption pressure is $2.5 \mathrm{MPa}$, the methane emission reaches the maximum value. However, the methane emission of free desorption is not significantly increased. This phenomenon proves that the gas injection displacement can help to ensure that the fracture is open and more methane would be released. When the free desorption continued, the gas pressure in the coal fracture dropped rapidly from $2.5 \mathrm{MPa}$, but the confining pressure was still $3 \mathrm{MPa}$. Hence, the internal coal fracture is closed or the opening degree is reduced, and the local gas pressure in the sealed fissure is kept at a high level, and the methane is difficult to be desorbed. But, when the nitrogen is injected with the pressure of $2.5 \mathrm{MPa}$, nitrogen gas pressure keeps the coal fissure open, the methane partial pressure decreases, thus enabling more methane release, cracks open and effect of nitrogen release of methane coerced is greatly increased.

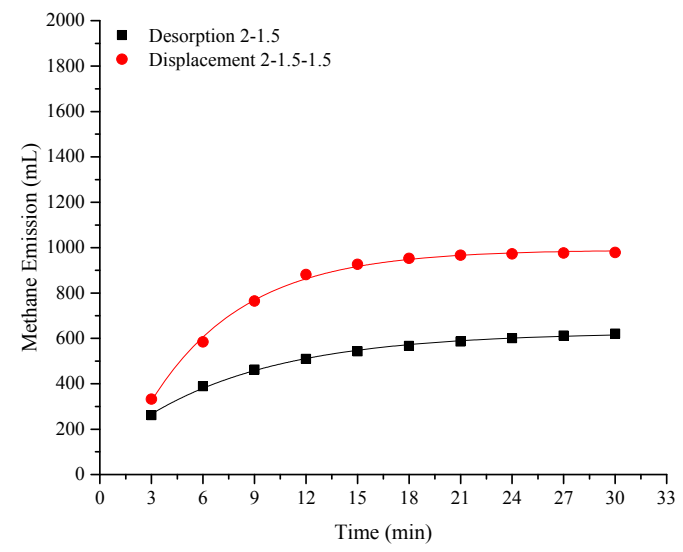

(a)

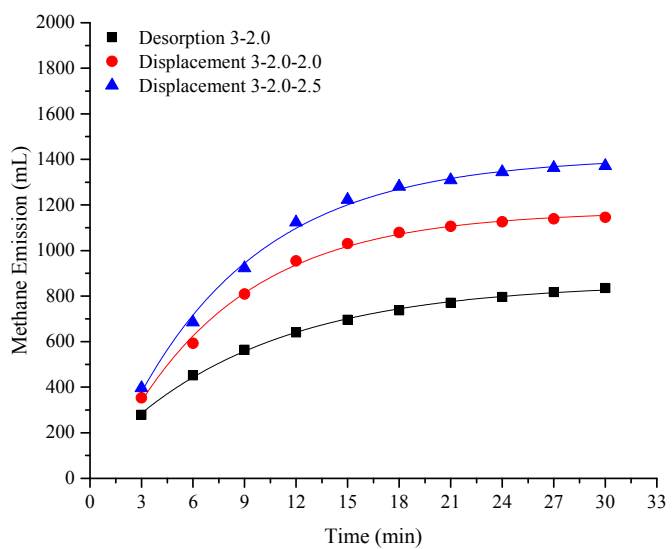

(c)

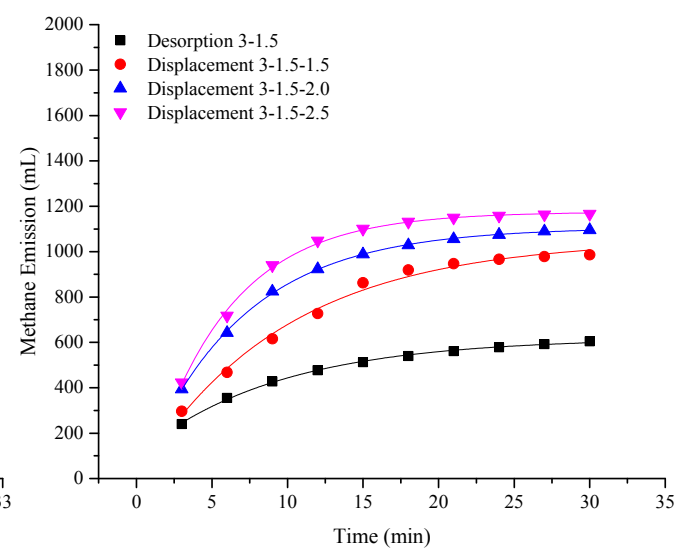

(b)

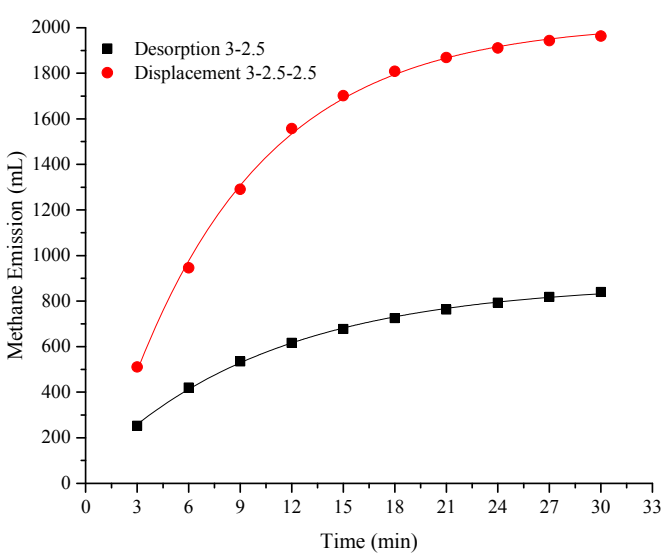

(d)

Fig. 4. The relationship of methane emission volume with experiment time

As shown in Fig. 4, in the latter half of the relationship curves, the curve of $\mathrm{N}_{2}$ injection displacement is more gentle than that of free desorption, which means $\mathrm{N}_{2}$ injection will promote the 
emission of methane more quickly. In fact, the time efficiency of free desorption and displacement desorption of methane is also different. 15 minutes free desorption, methane emissions accounting for the total percentage were $87.42 \%, 84.83 \%, 83.31 \%, 80.74 \%$; displacement desorption, 15 minute methane emissions accounting for the total percentage were $94.64 \%, 87.48 \%, 90.24 \%$, $94.35 \%, 89.94 \%, 89.14 \%, 86.65 \%$. From the data, the time efficiency of injecting nitrogen flooding is better than that of free desorption.

\subsection{Analysis of nitrogen consumption in displacement desorption}

After the nitrogen injection displacement experiment under different conditions, the methane emission volume and nitrogen consumption were obtained through the desorbed gas composition analysis and the data of flow meter. Based on the data in the table, the column chart below is drawn (Fig. 5). The displacement ratio is the ratio of nitrogen consumption to methane emission, which means the amount of nitrogen consumed by a unit of methane emission. The higher the displacement ratio, the lower the displacement efficiency.

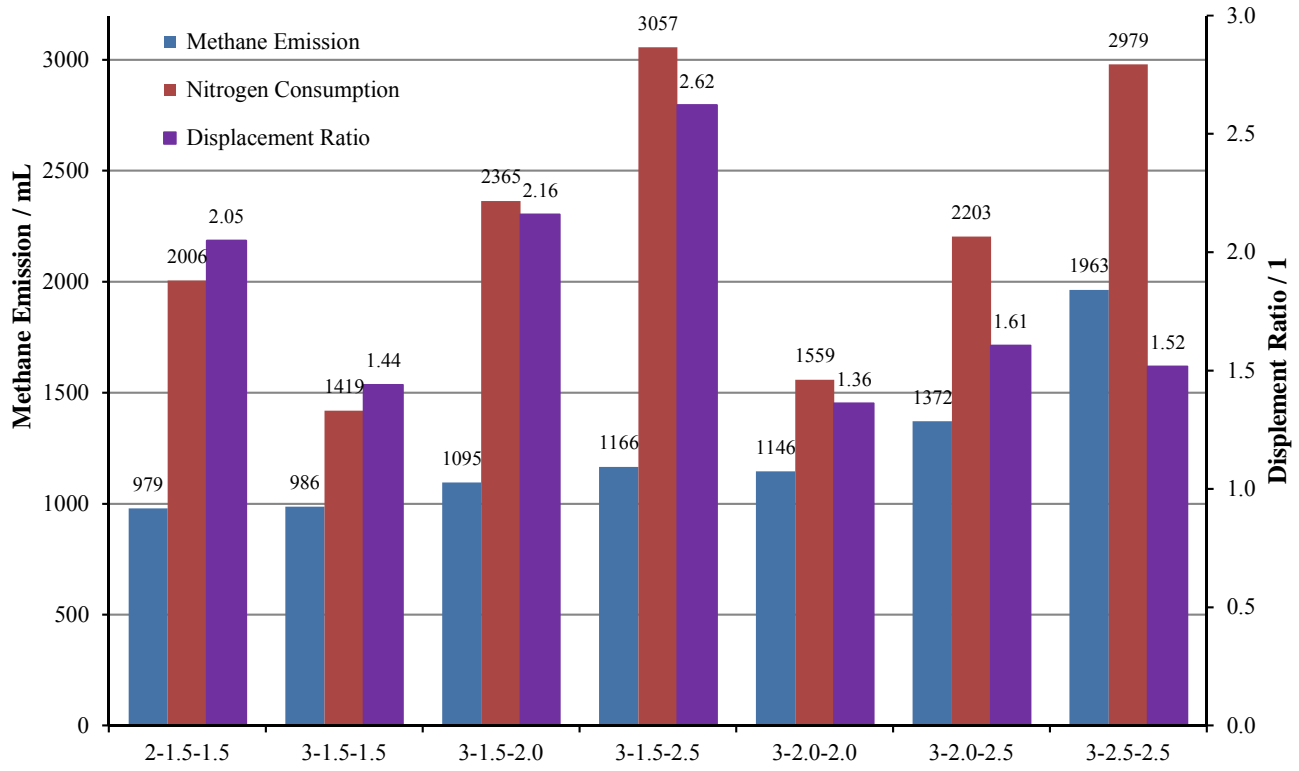

Fig. 5. Methane emission, nitrogen consumption and displacement ratio of the displacement experiment

As shown in Fig. 5, when the confining pressure is $3 \mathrm{MPa}$ and adsorption is $1.5 \mathrm{MPa}$, the methane emission volume under different conditions is kept at the same level, which is $986 \mathrm{~mL}$, $1095 \mathrm{~mL}$ and $1166 \mathrm{~mL}$. However, the nitrogen consumption increases rapidly with the increase of injection pressure, and reaches $1419 \mathrm{~mL}, 2365 \mathrm{~mL}$ and $3057 \mathrm{~mL}$. This indicates that the increase of gas injection pressure has no obvious effect on increasing the methane emission. 
When the confining pressure is $3 \mathrm{MPa}$ and the adsorption pressure and injection pressure are increased synchronously, the methane emission and nitrogen consumption are both increased steadily, and the displacement ratio is maintained at about 1.4. When the confining pressure is constant, the greater the injection pressure, the more conducive it is to the opening of the pores of the coal sample. As a result, more methane is released and more nitrogen is released. Under different conditions, the displacement ratio is between 1.3 and 2.7, which is quite different from the experiments result of 7.03-13.91 obtained by Liang (2010). When the adsorption pressure and gas pressure are maintained at $1.5 \mathrm{MPa}$, the displacement ratio is 2.05 and 1.44 when the confining pressure is $2 \mathrm{MPa}$ and $3 \mathrm{MPa}$, which means the smaller the confining pressure is, the higher the replacement ratio is. When the confining pressure is kept at $3 \mathrm{MPa}$ and the adsorption pressure was kept at $1.5 \mathrm{MPa}$, the displacement ratio is $1.44,2.16$ and 2.62 when the injection pressure was 1.5 MPa, 2.0 MPa, and 2.5 MPa, respectively, which means that the higher the injection pressure, the larger the replacement ratio. In other words, the displacement efficiency increases with the decrease of injection pressure, so as to the increase of the confining pressure.

In the experiment of nitrogen injection displacement, the relationship between the nitrogen consumption and experiment time also shows some characteristics. Fig. 6, obtained through the arrangement experiment data, shows the relationship between the nitrogen consumption and the experiment time. As shown in Fig. 6, the Lorentz curve is preferable for describing the relationship between nitrogen consumption and displacement time.

As shown in Fig. 6, when the confining pressure and the adsorption pressure remain constant, the higher the injection pressure is, the greater the nitrogen consumption will be. When the confining pressure and injection pressure remain constant, the adsorption pressure is higher or lower than that of the middle adsorption pressure. In addition, there is a general characteristic of the variation of nitrogen consumption with time. At first, the growth rate is quite slow, and the latter half curve is nearly linear. From the experimental data of nitrogen flooding, methane emissions already reached the $90 \%$ of the total in 15 minutes. Hence, after 15 minutes, the experiment is basically nitrogen seepage in coal sample. The gas permeability is calculated using the following formula.

$$
K=\frac{2 P_{0} Q_{0} \mu L}{A\left(P_{1}^{2}-P_{2}^{2}\right)}
$$

Where $K$ is the permeability of the coal sample, $P_{0}$ is the atmospheric pressure, $Q_{0}$ is the flow rate of the gas, $\mu$ is the viscosity of the gas, $L$ is the height of the coal sample, $A$ is the sectional area of the coal sample, $P_{1}$ is the inlet pressure, $P_{2}$ is the outlet pressure.

As shown in the Eq. (7), the gas flow rate is proportional to the square difference of the upstream and downstream gas pressure. When the injection pressure increases, the upstream and downstream gas pressure difference increases, the gas flow rate increases, hence the gas pressure increases, the nitrogen consumption increases. When the confining pressure increases, the fracture of coal sample is pressed and the opening is reduced, which leads to the decrease of the permeability of coal sample and the decrease in gas flow rate. On the whole, the pressure difference between upstream and downstream plays a major role in the control of nitrogen consumption, and the permeability plays a minor role. 


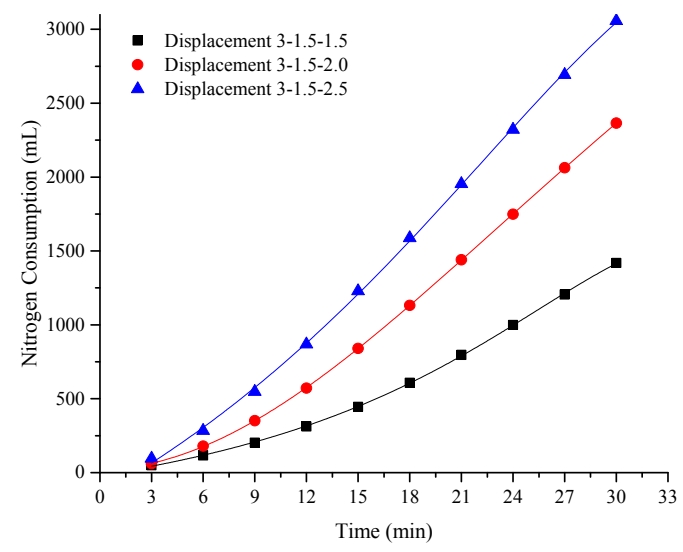

(a)

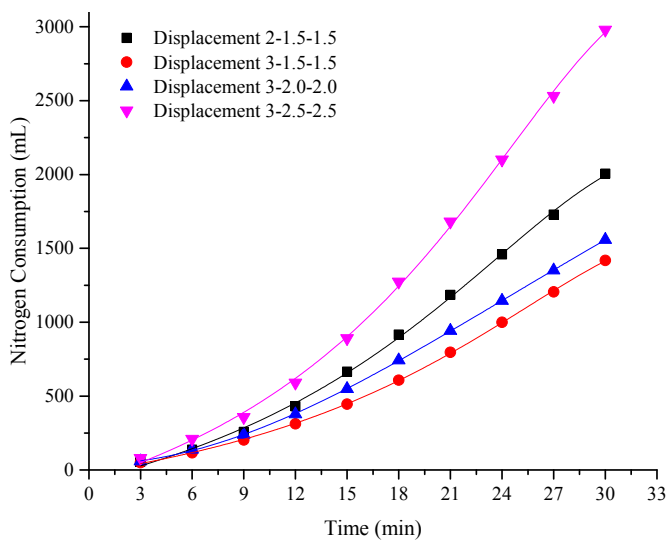

(c)

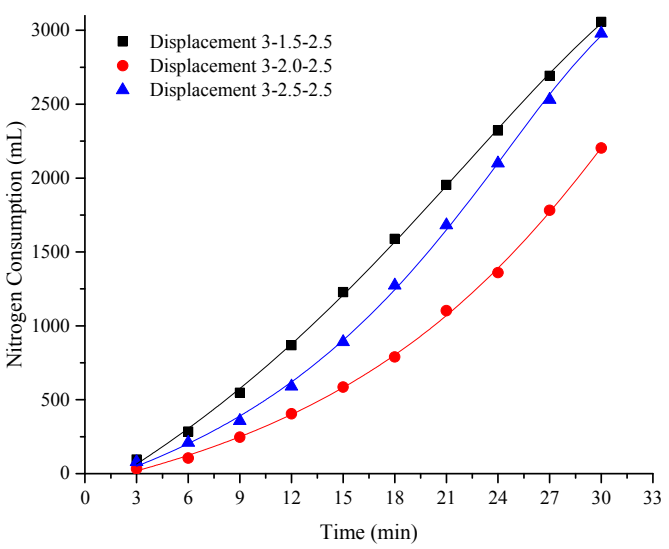

(b)

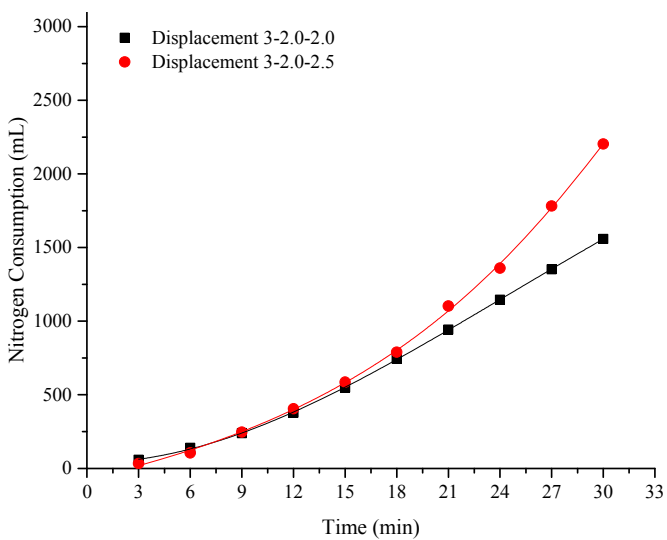

(d)

Fig. 6. the relationship of nitrogen consumption with experiment time

\subsection{Desorbed gas composition analysis}

The experiment data about desorbed gas composition are compared and the following figure shows the relationship between methane fraction and experiment time. And, the Boltzmann function is found to be preferable for describing the attenuation trend of methane fraction with displacement time.

The desorbed gas is the released mixture gas from the downstream of the high-pressure kettle after the injection of nitrogen into the coal sample, and the gas is collected using sampling bags every 3 minutes. When the concentration of methane in the mixture reaches a certain value, the mixed gas has the value of collection and utilization. The analysis of the components of the desorbed gas in the displacement experiment is helpful to predict the concentration of methane in the desorbed gas and to determine the cut-off time of the desorbed gas collection. The curve of methane fraction with time is an "inverted S" curve. In the initial stage of the methane composition ratio curve, no matter what the conditions, the methane fraction in the first 3 minutes 


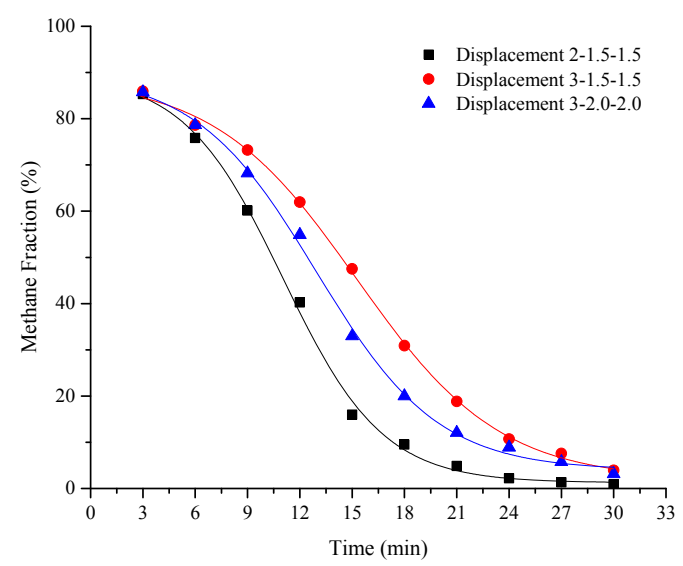

(a)

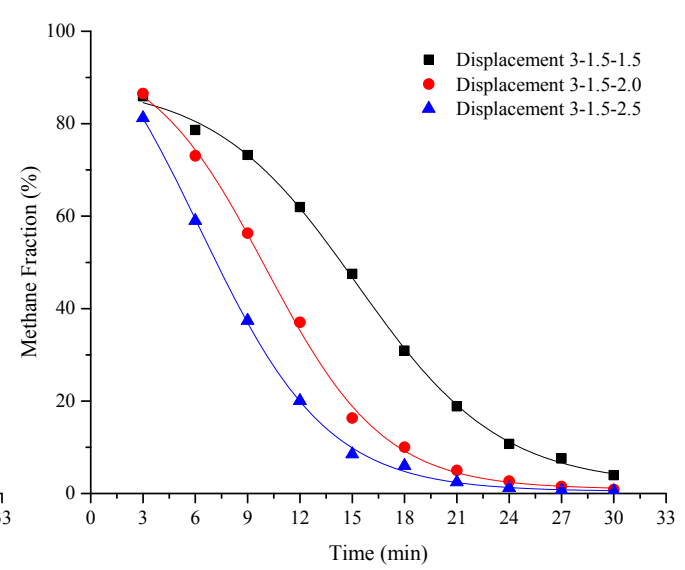

(b)

Fig. 7. the relationship of methane fraction with experiment time

is about $85 \%$, the methane fraction in the last 3 minutes is about $2.5 \%$. But the downward trend of each curve is apparently different under different conditions. Under the condition of the same adsorption pressure and injection pressure, the greater the confining pressure, the slower the decrease of the methane fraction. When the confining pressure and the adsorption pressure remain constant, the higher the injection pressure is, the faster the methane fraction decreases. When the confining pressure and injection pressure remain constant, the methane fraction decreases rapidly under the condition of low adsorption pressure.

In the initial stage of gas injection displacement, the driving force of methane desorption and release is the methane pressure potential caused by the opening of the valve on the downstream. From this point of view, when the injection pressure is closer to the adsorption pressure, the effect of displacement will be delayed, and the decrease of methane fraction is slower. When the adsorption pressure and injection pressure remain constant, the increase of confining pressure will result in the decrease of fracture opening, which will decrease the permeability of coal samples, and finally, lead to the delay of the displacement effect.

\section{Conclusions}

The thermogenic hypothesis and biogenic hypothesis are the two main formation theories of CBM. Due to the porous media properties of coal, CBM mainly exists at the adsorption state. Langmuir monolayer adsorption model, BET multilayer adsorption model and the theory of volume filling of micropore (TVFM) are the three most popular coal-methane adsorption models, which build the theoretical basis of gas injection improving the gas drainage.

The experiments indicate that displacement desorption releases more methane than free desorption under the same conditions. The increase in the injection pressure is helpful to release more methane. The pressure of injected nitrogen can keep the coal fracture open, which will be helpful to the emission of methane in the blind pores. In addition, the time efficiency of nitrogen injection displacement is better than that of free desorption. 
The higher injection pressure is helpful to promote methane emission, and also increase the displacement ratio. The displacement ratio of $\mathrm{N}_{2} / \mathrm{CH}_{4}$ indicates the methane emission efficiency of nitrogen injection, and the larger the displacement ratio is, the lower the displacement efficiency is. Experiments show that displacement efficiency increases with the decrease of injection pressure, so as to the increase of the confining pressure.

The nitrogen consumption increases slowly in the initial stage, and it is almost the linear growth in the latter half stage. The gas pressure difference between upstream and downstream plays a major role in the control of nitrogen consumption, and the axial permeability under the influence of confining pressure plays a minor role in the control of nitrogen consumption. With the composition analysis of the desorbed gas, it is found that the relationship between the methane component and the displacement time is an "inverted S" curve.

In this paper, the experiments prove that the methane emission amount of nitrogen injection is greater than that of free desorption, and the efficiency is also better than that of the free desorption. The mechanism of ECBM is explained by the permeability enhancement of gas injection. The higher injected gas pressure, the bigger the opening of the coal fracture, which ensures the unimpeded flow in methane release channel.

\section{Acknowledgments}

This research is supported by the Fundamental Research Funds for the Central Universities (2017XKZD06) and the Priority Academic Programme Development of Higher Education Institutions in Jiangsu Province. The authors wish to thank the staff and management of the Xutuan coal mine in Huaibei Mining Group for providing the coal samples and related data used in this study.

\section{References}

Busch A., Gensterblum Y., Krooss B.M., \& Siemons N., 2006. Investigation of high-pressure selective adsorption/ desorption behaviour of $\mathrm{CO}_{2}$, and $\mathrm{CH}_{4}$, on coals: an experimental study. International Journal of Coal Geology, $66(1-2), 53-68$.

Busch A., Gensterblum Y., Krooss B.M., 2003. Methane and $\mathrm{CO}_{2}$, sorption and desorption measurements on dry argonne premium coals: pure components and mixtures. International Journal of Coal Geology, 55 (2), 205-224.

Fang Z., 2009. Mechanisms and experiment study of gas mixture enhanced coalbed methane recovery technology. (Doctoral dissertation, Institute of Rock and Soil Mechanics, Chinese Academy of Sciences).

Fang Z., Li X., \& Wang G.G.X., 2013. A gas mixture enhanced coalbed methane recovery technology applied to underground coal mines. Journal of Mining Science, 49 (1), 106-117.

Harpalani S., And B.K.P., Dutta P., 2006. Methane/ $\mathrm{CO}_{2}$ sorption modeling for coalbed methaneCBM production and $\mathrm{CO}_{2}$ sequestration. Energy \& Fuels, 20 (4), 1591-1599.

Kotarba M.J., 2001. Composition and origin of coalbed gases in the upper silesian and lublin basins, Poland. Organic Geochemistry, 32 (1), 163-180.

Langmuir I., 1918. The adsorption of gases on plane surfaces of glass, mica and platinum. Journal of the American Chemical society, 40 (9), 1361-1403.

Liang W., Di W.U., Zhao Y., 2010. Experimental study of coalbeds methane replacement by carbon dioxide. Chinese Journal of Rock Mechanics \& Engineering, 29 (4), 665-673.

Lowell S., Shields J.E., 2013. Powder surface area and porosity (Vol. 2). Springer Science \& Business Media. 
Murray D.K., 1991. Coalbed methane; natural gas resources from coal seams. Geology in Coal Resource Utilization. United States: Tech Books, 97-103.

Oudinot A.Y., Schepers K.C., Reeves S.R., 2007. Gas injection and breakthrough trends as observed in ECBM sequestration pilot projects and field demonstrations. In Proceedings of the international coalbed methane symposium (pp. 24-25).

Pan Z., Connell L.D., 2007. A theoretical model for gas adsorption-induced coal swelling. International Journal of Coal Geology, 69 (4), 243-252.

Reeves S.R., Davis D., Oudinot A., 2004. A technical and economic sensitivity study of enhanced coalbed methane recovery and carbon sequestration in coal. DOE (March 2004). See: http://www. coal-seq. com/Proceedings2004/ TOPICALREPORT_Sensitivity_Study.pdf.

Reeves S., Oudinot A., 2004. The Tiffany Unit $N_{2}$-ECBM Pilot: A Reservoir Modeling Study. Advanced Resources International, Incorporated.

Saghafi A., Faiz M., Roberts D., 2007. $\mathrm{CO}_{2}$ storage and gas diffusivity properties of coals from Sydney basin, Australia. International Journal of Coal Geology, 70 (1-3), 240-254.

Sayyafzadeh M., Keshavarz A., 2016. Optimisation of gas mixture injection for enhanced coalbed methane recovery using a parallel genetic algorithm. Journal of Natural Gas Science and Engineering, 33, 942-953.

Scott A.R., 2002. Hydrogeologic factors affecting gas content distribution in coal beds. International Journal of Coal Geology, 50 (1-4), 363-387.

Shimada S., Li H., Oshima Y., Adachi K., 2005. Displacement behavior of $\mathrm{CH}_{4}$, adsorbed on coals by injecting pure $\mathrm{CO}_{2}, \mathrm{~N}_{2}$, and $\mathrm{CO}_{2}-\mathrm{N}_{2}$ mixture. Environmental Geology, 49 (1), 44-52.

Smith J.W., Pallasser R.J., 1996. Microbial origin of Australian coalbed methane. AAPG bulletin, 80 (6), 891-897.

Tao M., Wang W., Li J. et al., 2005. Secondary biogenic coalbed methane found in some coal fields in China. Chinese Science Bulletin. 50 (b10), 14-18.

Wang L., Wang Z., Li K., Chen H., 2015. Comparison of enhanced coalbed methane recovery by pure $\mathrm{N}_{2}$ and $\mathrm{CO}_{2}$ injection: Experimental observations and numerical simulation. Journal of Natural Gas Science and Engineering, 23, 363-372.

Yang H., Wei C., Wang Z., Yang T., 2010. Numerical simulation of coal-bed methane displacement by underground gas injection based on multi-physics coupling. Journal of China Coal Society, 35 (s1), 109-114.

Yi J., Akkutlu I. Y., Karacan C.Ö., Clarkson C.R., 2009. Gas sorption and transport in coals: a poroelastic medium approach. International Journal of Coal Geology, 77 (1-2), 137-144.

Zhang H., Wang T., Wei P., \& Zhang J., 2007. Study on the origins of coal-bed gas. Acta Petrolei Sinica, 28 (2), 29-34.

Zhang L., Aziz N., Ren T., Nemcik J., Tu S., 2014. Influence of coal particle size on coal adsorption and desorption characteristics. Archives of Mining Sciences, 59 (3), 807-820.

Zhang L., Aziz N., Ren T., Nemcik J., Tu S., 2015. Nitrogen injection to flush coal seam gas out of coal: an experimental study. Archives of Mining Sciences, 60 (4), 1013-1028.

Zhang L., Zhang C., Tu S., Tu H., Wang C., 2016. A study of directional permeability and gas injection to flush coal seam gas testing apparatus and method. Transport in Porous Media, 111 (3), 573-589. 